\title{
PELATIHAN PEMBUKUAN PRAKTIS BAGI \\ PENGUSAHA RABUK HARUAN \\ KECAMATAN BANJARMASIN UTARA KOTA BANJARMASIN
}

Ferra Maryana dan Masrifani

Jurusan Akuntansi dan Manajemen, STIE Nasional Banjarmasin

Email: eya_stienas@yahoo.com

\begin{abstract}
Rabuk haruan is a famous Banjarmasin culinary commodity. Rabuk haruan is also product of creative economy in culinary sub sector. But in practice, the owner of this enterprise especially in Banjarmasin Utara had not knew about their enterprise progress. It happened because of they never made ledger and report by continuity. That is why they need book keeping training to increase their competence that impact their ability to know their finance performance. The result showed there was difference value before and after the training with significance value is 0,000 . Therefore, it still need the BUM and government involvement to improved rabuk haruan performance.
\end{abstract}

Keywords: Rabuk haruan, creative economy, book keeping, training, finance performance

\section{PENDAHULUAN}

Menurut data yang dihimpun oleh Badan Pusat Statistik Indonesia tentang Ekonomi Kreatif (Ekraf) ada beberapa poin yang bisa disorot:

1. Kontribusi PDB Ekraf terbesar dihasilkan subsektor kuliner $(32,2 \%$ senilai $169,62 \mathrm{~T})$, fesyen $(28.1 \%$ senilai 147,6 T) dan kerajinan $(15,1 \%$ senilai $79,4 \mathrm{~T})$

2. PDB nominal Ekraf selalu mengalami trend yang meningkat, di tahun 2011 mencapai $526 \mathrm{~T}$, naik $0.16 \%$ dibanding 2010 yang mencapai 472,8 T

3. Tenaga kerja sektor Ekraf juga otomatis permintaannya meningkat di 2011 hingga mencapai 11,51 juta orang, naik 4,91\% dari 2010 yang hanya $11,49 \%$

4. Kontribusi tenaga kerja terbesar diserap subsektor Fesyen (32,4\% senilai 3,73 jt orang) kuliner $(32,1 \%$ senilai 3,7 jt orang), dan kerajinan (25,6\% senilai 2,95 jt orang).

( Kumara Sadana Putra, 2012 )

Usaha rabuk haruan merupakan usaha kuliner yang merupakan bagian dari ekonomi kreatif sekaligus sebagai usaha mikro, kecil dan menengah (UKM) yang mempunyai kedudukan, potensi dan peranan yang penting dan strategis dalam mewujudkan pembangunan ekonomi nasional seperti 
peningkatan kesempatan kerja dan pemerataan pendapatan.

Rabuk haruan atau abon dari ikan haruan adalah kuliner andalan kota Banjarmasin, karena ke khas rasanya dan hanya diproduksi di Kota Banjarmasin. Ikan Haruan adalah sejenis ikan buas yang hidup di air tawar. Kalau di Jawa dikenal dengan sebutan Kutuk/Gabus, orang Betawi menyebutnya Kocolan, sedangkan di Inggris, memanggil ikan Haruan ini dengan berbagai nama, seperti common snakehead, snakehead murrel, chevron snakehead, striped snakehead dan juga aruan. Sedangkan nama ilmiahnya adalah Channa striata. Dinamakan Snake head, mungkin karena kepala ikan Haruan berkepala besar agak gepeng mirip kepala ular dengan sisiksisik besar di atas kepala.Tubuh bulat gilig memanjang, seperti peluru kendali.Sirip punggung memanjang dan sirip ekor membulat di ujungnya.Biasanya dijumpai di danau, rawa, sungai, dan saluran-saluran air hingga ke sawah-sawah. Ikan Haruan ini memangsa aneka ikan kecil-kecil, serangga, dan berbagai hewan air lain termasuk berudu dan kodok.

Sering terjadi ikan haruan terbawa banjir ke parit-parit di sekitar rumah, atau memasuki kolam-kolam pemeliharaan ikan dan menjadi hama yang memangsa ikan-ikan peliharaan di sana. Jika sawah, kolam atau parit mengering, ikan ini akan berupaya pindah ke tempat lain, atau bila terpaksa, akan mengubur diri di dalam lumpur hingga tempat itu kembali berair. Oleh sebab itu ikan ini sering kali ditemui 'berjalan' di daratan, khususnya di malam hari di musim kemarau, mencari tempat lain yang masih berair. Fenomena ini adalah karena haruan memiliki kemampuan bernapas langsung dari udara, dengan menggunakan semacam organ labirin (seperti pada ikan lele atau betok) namun lebih primitif. Salah satu kerabat dekat gabus adalah ikan Toman (Channa micropeltes), yang panjang tubuhnya dapat melebihi $1 \mathrm{~m}$ dan beratnya lebih dari $5 \mathrm{~kg}$.

Di Kalimantan Selatan termasuk kota Banjarmasin, ikan Haruan ini mempunyai nilai ekonomis yang cukup tinggi. Biasanya ikan ini diasinkan terlebih dahulu sebelum diperdagangkan antar pulau. Haruan asin merupakan salah satu ikan kering yang cukup mahal harganya. Untuk ikan Haruan segar, kebanyakan dijual dalam keadaan hidup, juga merupakan 
sumber protein yang sangat tinggi yaitu Albumin. Albumin diperlukan tubuh manusia setiap hari, terutama dalam proses penyembuhan luka-luka. Bahkan, di daerah pedesaan, anak lakilaki pasca dikhitan selalu dianjurkan mengonsumsi ikan sejenis itu untuk mempercepat proses penyembuhan. Caranya, daging ikan tersebut dikukus atau di-steam sehingga memperoleh filtrate, yang dijadikan menu ekstra bagi penderita hipoalbumin dan luka.
Selain itu, menurut Prof Madya Dr. Saringat Baie seorang peneliti yang menghasilkan tablet obat luka dari ikan haruan, ikan haruan juga mengandung asam amino dan lemak yang dapat menyembuhkan luka dalam perut serta amat baik untuk mengobati penyakit gastrik. Syaratnya, Haruan tersebut harus haruan liar dan bukan haruan yang dibudidayakan.

Berikut ini deskripsi dari usaha rabuk haruan ditinjau dari aspek produksi dan manajemen usaha:

\begin{tabular}{|c|c|c|}
\hline Keterangan & $\begin{array}{l}\text { Rabuk Haruan } \\
\text { UD Ananda }\end{array}$ & $\begin{array}{c}\text { Rabuk Haruan } \\
\text { Kakaktua }\end{array}$ \\
\hline $\begin{array}{l}\text { Aspek Produksi : } \\
\text { 1.Lokasi Usaha } \\
\text { 2.Jumlah tenaga kerja } \\
\text { 3.Tingkat pendidikan } \\
\text { 4.Izin Usaha } \\
\text { 5.Jumlah produksi per } \\
\text { bulan } \\
\text { 6.Lama pembuatan } \\
\text { 7.Tehnologi } \\
\text { 8.Jenis Bahan baku } \\
\text { 9.Kemudahan memperoleh } \\
\text { 10.Proses produksi } \\
\text { 11.Pengemasan produk } \\
\end{array}$ & $\begin{array}{l}\text { Banjarmasin Utara } \\
6 \text { orang } \\
2 \text { org SMP, } 4 \text { org SMA } \\
\text { Keterangan dari kelurahan } \\
300 \mathrm{~kg} \\
10 \text { jam } \\
\text { Manual } \\
\text { Ikan haruan } \\
\text { Cukup sulit } \\
\text { Pesanan dan proses } \\
\text { Dibungkus plastik biasa }\end{array}$ & $\begin{array}{l}\text { Banjarmasin Utara } \\
5 \text { orang } \\
2 \text { org SMP, } 3 \text { org SMA } \\
\text { Keterangan dari kelurahan } \\
200 \mathrm{~kg} \\
10 \text { jam } \\
\text { Manual } \\
\text { Ikan haruan } \\
\text { Cukup sulit } \\
\text { Pesanan dan proses } \\
\text { Toples Plastik }\end{array}$ \\
\hline $\begin{array}{l}\text { Aspek Manajemen Usaha } \\
\text { 1. Omzet penjualan/bulan } \\
\text { 2. Volume penjualan/bulan } \\
\text { 3. Jumlah modal usaha } \\
\text { 4. Sumber modal usaha } \\
\text { 5. Investasi alat produksi } \\
\text { 6. Biaya produksi perbulan } \\
\text { 7. Keuntungan per bulan } \\
\text { 8. Pencatatan transaksi } \\
\text { 9. Daerah pemasaran } \\
\end{array}$ & $\begin{array}{l}\text { Rp.65.000.000,- } \\
200-300 \mathrm{~kg} \\
\text { Rp.40.000.000,- } \\
\text { Sendiri dan keluarga } \\
\text { Rp.5.000.000,- } \\
\text { Rp.35.000.000,- } \\
\text { Rp.10.000.000,- } \\
\text { Tidak tercatat } \\
\text { Kal-Sel dan Jawa } \\
\end{array}$ & $\begin{array}{l}\text { Rp.15.000.000,- } \\
100-200 \mathrm{~kg} \\
\text { Rp.15.000.000,- } \\
\text { Sendiri dan keluarga } \\
\text { Rp.5.000.000,- } \\
\text { Rp.7.000.000,- } \\
\text { Rp.3.000.000,- } \\
\text { Tidak tercatat } \\
\text { Kal-Sel dan Jawa } \\
\end{array}$ \\
\hline
\end{tabular}

Tabel 1 Kondisi Usaha Rabuk Haruan di Kecamatan Banjarmasin Utara 
Usaha rabuk haruan ini berpotensi untuk dikembangkan, produk turun temurun dan berdaya saing sehingga mempunyai makna sebagai pelestarian budaya daerah Kalimantan Selatan dan dapat memberikankontribusi berupa pendapatan bagi pengusaha dan karyawannya, menyerap tenaga kerja pada daerah sekitar usaha, serta akan memberikan pendapatan pada pemerintah daerah karena pajak yang dibayarkannya apabila produk ini dipasarkan baik pada pasar lokal, regional maupun nasional.

Berdasarkan tabel di atas terlihat bahwa kedua usaha tersebut tidak pernah melakukan pencatatan transaksi secara terus menerus. Hal ini menyebabkan perusahaan sulit untuk memantau perkembangan usaha. Selain itu akan sulit untuk mengajukan pinjaman sebagai tambahan modal kerja karena perusahaan tidak menyusun laporan keuangan serta kesulitan melaporkan $\mathrm{PPh}$ Masa karena tidak mengetahui secara pasti jumlah omzet yang diperoleh. Padahal pemerintah telah memberikan kemudahan untuk penyetoran pajak bagi usaha yang memiliki omzet kurang dari 4,8 milyar per tahun maka jumlah pajak yang dilaporkan dan disetorkan hanya sebesar $1 \%$ dari jumlah omzet (PPh Pasal 46).

\section{METODE PELAKSANAAN}

Permasalahan yang dihadapi mitra adalah belum dilaksanakannya pembukuan/catatan secara terus menerus yang mengakibatkan mitra usaha tidak dapat mengetahui perkembangan usaha secara pasti. Akibatnya perusahaan tidak mengetahui apakah mereka mengalami keuntungan atau kerugian secara akuntansi serta kesulitan dalam pelaporan dan penyetoran pajak. Maka diperlukan pelatihan dan pendampingan bagi mitra usaha sehingga dapat meningkatkan kemajuan usaha serta dapat memperoleh tambahan modal kerja dengan mengajukan proposal pinjaman kepada BUMN berdasarkan laporan keuangan yang mampu mereka susun.

Agar dapat mengevaluasi kegiatan pelatihan ini maka akan dilakukan penilaian sebelum dan sesudah pelatihan (pre-test dan post test). Penilaian dilakukan untuk menilai kemampuan peserta pelatihjan sebelum dan sesudah menerimka pelatihan yang diberikan. Hasil penilaian akan diuji menggunakan paired sample $t$ test dengan alat bantu software SPSS versi 
22. Hasil pengujian akan menunjukkan ada perbedaan jika nilai signifikansi < 0,05 sementara jika nilai signifikansi > 0,05 maka berarti tidak terdapat perbedaan hasil penilaian sebelum dan sesudah pelatihan.

\section{KELAYAKAN PENGABDI}

Pelaksana kegiatan pengabdian ini adalah para dosen yang ahli pada bidang akuntansi, manajemen dan perpajakan. Hal ini dilakukan dalam rangka menunjang terwujudnya kegiatan pengabdian ini. Keterkaitan antara kompetensi tim,. Pembagian tugas, serta luaran yang diharapkan untuk mengatasi masalah yang dihadapi usaha mitra dapat dilihat pada gambar berikut:

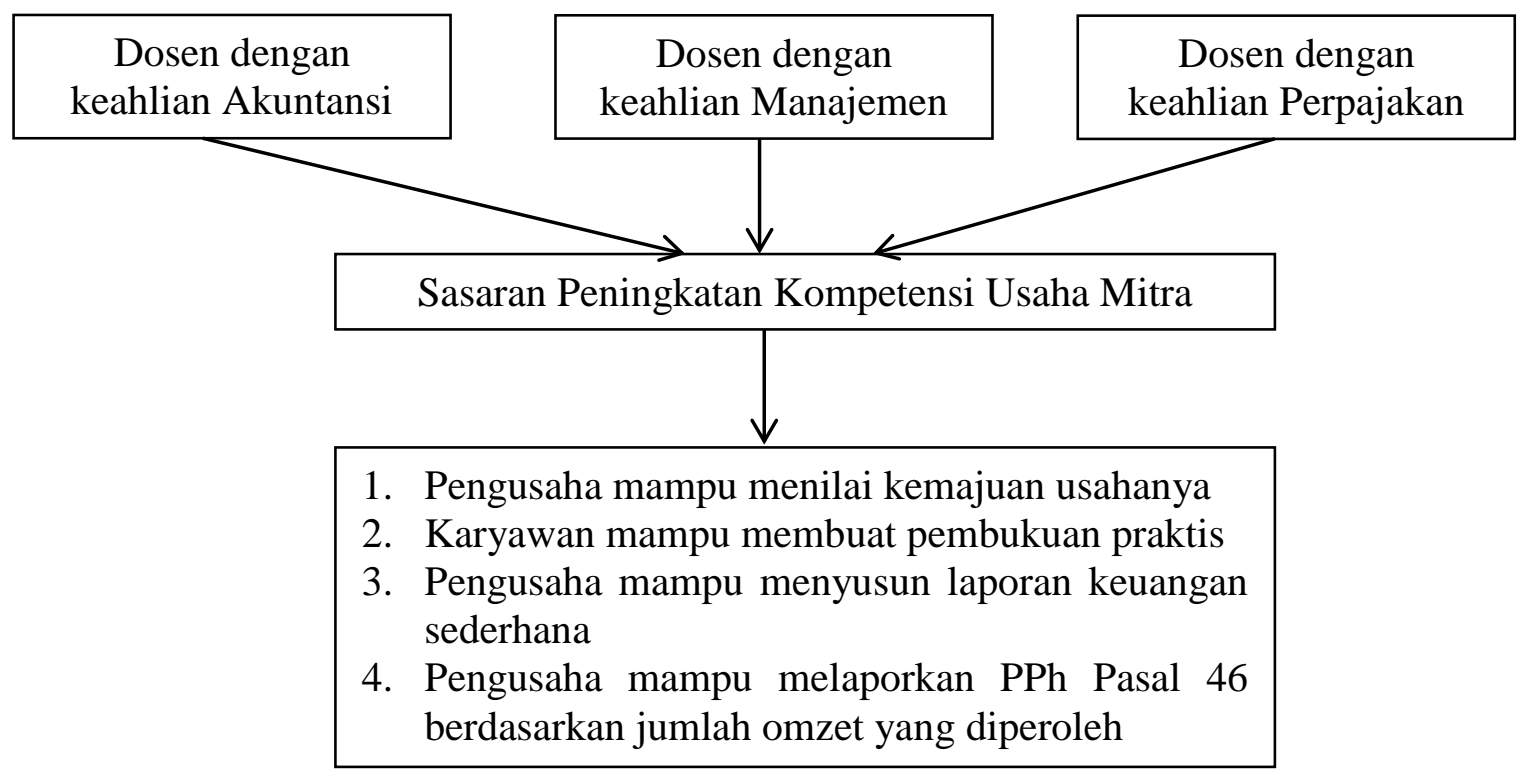

Gambar 1 Kompetensi Tim Pelaksana

\section{HASIL YANG DICAPAI}

Pelatihan ini diikuti oleh pemilik usaha mitra serta karyawannya masingmasing sebanyak 5 orang hingga total peserta sebanyak 10 orang dengan pendidikan minimal SLTA sederajat. Fokus pelatihan ini adalah materi pembukuan praktis yang terdiri dari dokumen minimal yang harus dimiliki, catatan akuntansi serta laporan keuangan sederhana. Pemberian materi ini sangat diperlukan sebagai dasar untuk menentukan kemajuan usaha (untung atau rugi), jumlah omzet yang diperoleh serta perhitungan $\mathrm{PPh}$ pasal 46 yang harus dilaporkan dan disetor. Berikut hasil Pre Test dan Post Test peserta pelatihan: 


\begin{tabular}{|c|c|c|}
\hline \multirow{2}{*}{ Peserta Ke- } & \multicolumn{2}{|c|}{ Nilai } \\
\cline { 2 - 3 } & Pre Test & Post Test \\
\hline 1 & 60 & 90 \\
\hline 2 & 50 & 80 \\
\hline 3 & 50 & 80 \\
\hline 4 & 40 & 70 \\
\hline 5 & 70 & 100 \\
\hline 6 & 60 & 100 \\
\hline 7 & 60 & 90 \\
\hline 8 & 40 & 80 \\
\hline 9 & 40 & 80 \\
\hline 10 & 30 & 80 \\
\hline
\end{tabular}

Tabel 2 Hasil Pre Test dan Post Test

Sumber: data diolah (2017)

Nilai pre test dan post test jika

diuji menggunakan paired sample t test

dapat dilihat pada tabel berikut:

Paired Samples Statistics

\begin{tabular}{|rl|r|r|r|r|}
\hline & & \multicolumn{1}{|c|}{ Mean } & N & Std. Deviation & Std. Error Mean \\
\hline \multirow{2}{*}{ Pair 1 } & PRETEST & 50.00 & 10 & 12.472 & 3.944 \\
& POSTTEST & 85.00 & 10 & 9.718 & 3.073 \\
\hline
\end{tabular}

Paired Samples Correlations

\begin{tabular}{|lc|r|r|r|}
\hline & & $\mathrm{N}$ & Correlation & \multicolumn{1}{c|}{ Sig. } \\
\hline Pair 1 & PRETEST \& POSTTEST & 10 & .825 & .003 \\
\hline
\end{tabular}

\section{Paired Samples Test}

\begin{tabular}{|c|c|c|c|c|c|c|c|c|}
\hline & \multicolumn{5}{|c|}{ Paired Differences } & \multirow[b]{3}{*}{$t$} & \multirow[b]{3}{*}{$d f$} & \multirow[b]{3}{*}{ Sig. (2-tailed) } \\
\hline & \multirow[b]{2}{*}{ Mean } & \multirow[b]{2}{*}{ Std. Deviation } & \multirow{2}{*}{$\begin{array}{l}\text { Std. Error } \\
\text { Mean }\end{array}$} & \multicolumn{2}{|c|}{$\begin{array}{c}\text { 95\% Confidence Interval of the } \\
\text { Difference }\end{array}$} & & & \\
\hline & & & & Lower & Upper & & & \\
\hline Pair 1 PRETEST-POSTIEST & .35 .000 & 7.071 & 2.236 & -40.058 & -29.942 & -15.652 & $g$ & .000 \\
\hline
\end{tabular}

Tabel 3 Hasil Uji Paired Sample t Test

Sumber: Output SPSS

Berdasarkan uji Paired Sample t

Test di atas terlihat nilai mean untuk pre test sebesar 50,00 dan untuk post test sebesar 85,00. Hal ini menunjukkan 
bahwa nilai setelah pelatihan lebih tinggi dibandingkan sebelum pelatihan. Hal ini juga diperkuat dengan nilai signifikansi sebesar 0,000 $<0,05$ yang menunjukkan terdapat perbedaan nilai sebelum dan sesudah pelatihan

Berdasarkan temuan di atas, maka dapat disimpulkan bahwa pelatihan pembukuan praktis yang diberikan kepada pemilik usaha rabuk haruan dan karyawannya mampu meningkatkan kompetensi mereka dalam membuat pembukuan dan laporan keuangan. Hal ini akan berdampak terhadap kemampuan mereka untuk melaporkan pajak $\mathrm{PPh}$ Pasal 46 serta memudahkan mereka dalam pengajuan modal kerja ke BUMN atau perbankan.

\section{KESIMPULAN DAN SARAN}

Pelatihan yang dilakukan oleh dosen yang memiliki keahlian di bidang akuntansi, manajemen dan perpajakan menghasilkan nilai post test yang lebih baik dibandingkan nilai pre test. Hasil ini menyimpulkan bahwa melalui pelatihan mampu untuk meningkatkan kompetensi pemilik usaha mitra dan karyawannya sehingga dapat memberikan salah satu solusi bagi perusahaan untuk menilai kemajuan usahanya.

Namun demikian, pelatihan yang melibatkan dosen dan para pelaku usaha usaha saja belum cukup optimal memberikan kompetensi bagi para pelaku usaha. Hal ini dikarenakan berbedanya latar belakang pendidikan para pelaku usaha. Sehingga keterlibatan dari pihak BUMN dan pemerintah dirasa perlu agar para pelaku usaha memahami betul bagaimana cara meningkatkan modal kerja serta kemajuan usaha mereka.

\section{DAFTAR PUSTAKA}

Badan Pusat Statistik Indonesia. 2012.Statistik Ekonomi Kreatif. Jakarta. PPKI. 2012. Buku Program PPKI 2012. Jakarta

Kumara Sadana Putra, 2012. Meneropong Industri Kreatif Indonesia dari Pameran Produk Kreatif Indonesia (PPKI), 29 Nopember 2012 